\title{
Preparing Students For An Online Accounting Course
}

Barbara W. Scofield, University of Dallas, USA Robert J. Walsh, University of Dallas, USA

\begin{abstract}
Accounting education has been under intense examination for at least the past 20 years (American Accounting Association, 1986; Big Eight Accounting Firms, 1989; AECC, 1990). Similarly, the value of an MBA education has been scrutinized (Leonhardt, 2000 and Mintzberg and Lampel, 2001). Over the past 10 years, online education has grown exponentially with the Internet (Bryant, Kahle and Schafer, 2005). This paper examines the responses of students who have just completed an online MBA financial accounting course to the question "What advice would you give someone who is about to take the course?" Over 60 students were polled, and their answers categorized into 36 repeated recommendations and seven themes: Input Factors, Communication, External Activities, Technical Skills, Study Tips, Personal Factors, and Course Characteristics. By far the predominate factor mentioned was time, but the breadth of additional advice provides a snapshot for educators of the student point of view. The results of this study are useful to any professor who has taught or will be teaching an online financial accounting course.
\end{abstract}

\section{INTRODUCTION}

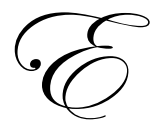

ntering MBA students most often take a course in financial accounting as part of the program. Many studies have tried to predict the best preparation for these students, prior to enrolling in the course. Several studies have explained performance in the undergraduate accounting course (Bergin, 1983, Gist et al., 1996) and at the MBA level (Krausz, et al., 1999). Few studies have examined this issue at the MBA level within an online course.

All three of these elements - accounting education, MBA education, online education - have been under prolonged research and examination for a decade or more. Accounting education has been under intense examination for at least the past 20 years (American Accounting Association, 1986; Big Eight Accounting Firms, 1989; AECC, 1990). Similarly, the value of an MBA education has been scrutinized (Leonhardt, 2000 and Mintzberg and Lampel, 2001). Over the past 10 years, online education has grown exponentially with the Internet (Bryant, Kahle and Schafer, 2005), and many, many authors have provided advice and guidance on best practices.

This paper examines all three aspects in one study, looking at the question of how to best equip students to succeed in an online introduction to financial accounting course at the MBA level. One open-ended question was asked at the end of the course, "What advice would you give to someone who is about to take the course?" While many students offered advice, they also offered observations (which almost always correlated with the advice). In addition, asking traditional age undergraduates this question may not yield well-informed or useful results (many traditional undergraduates do not take a large number of online courses), but this study poses the question to parttime MBA students, almost all working adults, most of them working and studying in the metropolitan area of Dallas-Fort Worth, and many who have some experience in online classes. The results should be of interesting to anyone teaching an online MBA financial accounting course in the future.

This paper is outlined as followed. Section two discusses some of the literature in each of the three areas addressed by this paper: accounting education, MBA education, and online education. Section three provides an overview of the study, including the background characteristics of the students. Section four provides results and section five offers a conclusion. 


\section{LITERATURE REVIEW}

Accounting education, MBA education, and online education each have their own set of challenges, critiques and criticism. Each, during the past decade, has received enormous amounts of press coverage - from the advent of the widespread use of the Internet which allows online courses at any university, to the Enron debacle, to the continuing debate over the usefulness and necessity of graduate business education. This section will briefly summarize some of the literature in each area.

\section{A. Accounting Education}

The literature on accounting education, by and large, has been concentrated on undergraduate accounting programs (plus the 150 hour rule, which, depending on your state, might still be within undergraduate education). In general, in addition to how best prepare students to enter an accounting course, research has examined the course itself, the course within the context of an accounting major, and the major within the context of what employers want from an accounting major.

Beginning in the decade of the 1980s, accounting education faced increased scrutiny and evaluation. The Bedford Committee Report (American Accounting Association, 1986) initiated this wave by examining the changing roles of accounting and accountants in the world, under the "expanding professions" mantra. Next, in 1989, the then Big Eight, in "The White Paper," described the education and knowledge an accountant should have in the workplace (Big Eight Accounting Firms, 1989). The Accounting Education Change Commission followed with a series of studies and directives on the skill set required by accounting majors. Their first study, released in 1990 (AECC, 1990), found seven characteristics which are important predictors for a successful accountant: a) accounting degree, b) grade point average, c) accounting grade point average, d) communication ability, e) personal integrity, f) energy, and g) appearance.

Throughout the decade of the 1990s, after the passage of the 150 semester hour requirement by the AICPA, smaller studies have sought to find even more "characteristics" of the successful accountant, in terms of education, personality, the ability to communicate orally and through writing, among other things. These studies have led to even more calls to improve the education of accounting students and the suggested curricular changes needed (for example, see Needles and Powers, 1990, Levy and Klein, 1993, and Novin, Fetyko and Tucker, 1997). Other studies have researched upper-level accounting courses, including how to apply general accounting rules to broadbased business questions (see Pratt and Davey, 1997 and Davidson and Baldwin, 2005).

While some studies have examined how to improve the accounting major or the course by asking alumni (Teo, et al., 1993), other researchers have examined how to improve the students' ability before entering the course. Krausz et. Al. (1999) explored the relationship between performance in the first accounting course at the MBA level with prior accounting work experience and undergraduate coursework in accounting. Results from their work suggested that both education and work experience are both necessary for either one to be helpful to the student. Ward et al. (1993) found a positive relationship between both composite and math ACT scores and performance of African-American accounting students. Chewning and Spiller (1999) found a series of factors (including work experience and prior course work in accounting) that should allow students to exempt the required core course in accounting and move on to higher level accounting courses.

\section{B. MBA Education}

Concurrent with debate about accountants and accounting education over the past two decades, another series of questions has been raised by employers with respect to the usefulness of business education in general. These perceived doubts have been particularly keen at the graduate and MBA level, where many employers reimburse their employees for either all or part of their graduate business education if they continue to work fulltime while attending classes part-time. Employers often want immediate or near immediate payoff for those expenditures (Byrne, 1991). Recently, some prestigious MBA programs (for example, Stanford University) are allowing students to "tailor" almost their entire MBA program based on their interests (as well as their perceived future employment opportunities). 
Questioning whether education is useful is certainly not new - and in MBA arena, the question has been asked persistently. A variety of writers and researchers have questioned the value of graduate education in business (Leonhardt, 2000; Mintzberg and Lampet 2001 and Mintzberg and Gosling, 2002). For example, Pfeffer and Fong (2002) summarize their findings regarding the value of MBA degrees:

The data suggests that business schools are not very effective: neither possessing an MBA degree nor grades earned in courses correlate with career success, results that question the effectiveness of schools in preparing their students.(p.78)

On the other hand, within the accounting area, a recent study by Hunton, Stone and Wier (2005) (HSW) examined the usefulness of a Masters in Accounting (M.Acc.) and the MBA degree. HSW found, through examining performance reports of management accountants from over 2,000 firms, that accountants with advanced degrees perform better (albeit slightly) than those without a masters degree:

Specifically, a M.Acc. degree provides greater benefit than a MBA in the early and middle career years, while an MBA degree provides greater benefit than a M.Acc. in later career years. Consequently, our data suggest that graduate business education provides value to a managerial accountants' success, but the specific benefit provided, and the timing of the benefit, depend on the type of degree. (p.96)

Within this backdrop comes the question as to what are the most useful topics in any MBA course, or in our case, the introductory accounting course. Hermanson, Hermanson and Alsup (1998) (HHA) examined the accounting component of 27 executive MBA programs. Their study was motivated by their belief that:

In contrast to the well-developed literature on undergraduate accounting curricula, there appears to be very little information available on the accounting component of E.MBA programs or even traditional MBA programs. Benchmarking studies of E.MBA and MBA programs performed by the Executive MBA Council and the AACSB provide only limited, summary information on the handling of accounting in such programs. (p.802)

HHA questioned the MBA director (or the faculty member/chair of the MBA curriculum committee) on the coverage of specific accounting topics (within the areas of auditing, financial and managerial accounting). They found that most auditing topics ranked low in coverage, while certain select area in financial accounting (like basic financial reporting and financial statement analysis) and in managerial accounting (like cost behavior and activitybased costing) ranked high.

\section{Online Education}

Online education in accounting over the past decade has seen dramatic growth, and researchers have examined these phenomena in a variety of ways (for reviews of the literature, see Bryant et al., 2005 and Watson, et al., 2003). Studies have examined the characteristics of a successful course and the burdens placed on the institution, faculty and students by online courses.

Characteristics of a successful course generally include the ability to interact with students, along with the producing learning outcomes similar to an on campus courses. Studies have examined the interaction and communications within a course, with a positive correlation between increased interaction and both student achievement and satisfaction (Roblyer and Wiencke, 2003). Researchers have also found that students want outcomes which are equivalent to a traditional on-campus course (Simonson et al. 2002). Educators have also shared successful tips for course teaching and student learning (for example, see Walsh (1999)).

The burden of online courses is also a focal point of investigations. Palloff and Pratt (1999) suggested that the preparation time for an online course is at least 2.5 times that of a face-to-face course. Development costs often run high, including the additional server capacity required at the college level, and computer administrators to run and maintain the hardware and course software. The attrition rate from a 1999 study by Phipps and Merisotis found that distance education course averaged more than $30 \%$, compared to $5 \%$ or less for a traditional, on campus course. 
Students have had many difficulties within these courses as well. Students need to be self-directed and intrinsically motivated (Irizarry, 2002) as well as intelligent, emotionally stable, trusting, passive and conforming than other students (Biner, 1995). Within the course, feedback needs to be prompt and precise (Muirhead, 2002), and engagement of students frequent and continuous over the entire course (Roblyer and Wiencke, 2003).

\section{OVERVIEW OF THE STUDY}

Online accounting students are experts in being themselves - students taking distance education courses. Thus to explore the elements that lead to best practices for preparation in taking online accounting courses, the students themselves were asked to provide narrative recommendations as if to future online graduate accounting students. These texts were then analyzed using the qualitative data paradigm of Auerbach and Silverstein (2003) as outlined below.

\section{A. Participants}

Sixty-two students from three sections of online graduate financial accounting provided a paragraph-long written response to the question, "What advice would you give someone who is about to take the course?" These students all completed a course that covered the complete text Introduction to Financial Accounting, $9^{\text {th }}$ edition by Horngren et al., taught by the same full-time instructor over three successive trimesters. Most students were in the beginning of their graduate degree, but had significant professional or technical work experience (average: 7.46 years; median: 6.00 years; standard deviation: 5.85 years) that matched with their average age of 37 (median 36; standard deviation: 8.05$)$. There were more men than women (56\% vs. $44 \%)$. These students were in their first semester (41.94\%) or had complete only 1 to 3 courses previously (29.03\%). Only a small portion was more than half way through the graduate program (6.45\%). For most students, this was their first online course (59.68\%), but more than $40 \%$ had taken an online course before, and half of the students expected to take their entire graduate program through the online program. More than 1/3 (37.10\%) were known to have taken a college level accounting course previously. ${ }^{1}$ This profile of participants describes mid-career part-time graduate business students whose experience as students can provide valuable insight into their own experience (see Table 1).

\section{B. Data and Methodology}

The data used in this paper is the narrative paragraphs written by the students who completed their first accounting class in the MBA program. Thus the information is qualitative and demands a qualitative analysis methodology. This paper uses the methodology of Auerbach and Silverstein (2003) that lets the issues arise from the data collected based on a transparent and systematic investigation. ${ }^{2}$ While participants in such research are typically interviewed one-on-one or in small focus groups, the participants in this study provided their response as a written 10-point essay question on a 150-point cumulative final exam. This collection method ensured information from a larger set of online students who took the question seriously than could be expected in a survey setting. The examination setting of this question could lead to deficient answers if the students rushed through this question or misunderstood the intent of the question, since no direct observation or follow-up questions were present. However, there is no indication that students were unduly time-constrained on the exam, and the average length of the answers suggests that they attended to the task (average: 121 words; median: 119 words; standard deviation: 68 words).

\section{Analysis}

The following procedure was used to analyze the data. The responses were pasted from the online exam into a spreadsheet and assigned an anonymous identification number. One researcher then read through the entire set of responses, highlighting the responses relevant to the issue of what prepares students for success in online education. ${ }^{3}$ The information deemed irrelevant for the purposes of this paper included all of the material that could not be considered true "advice." A sample that demonstrates the selection of relevant text is provided in Table 2. Focusing the research on the relevant text reduces the amount of material and allows for an exhaustive sorting of the responses into repeating groups of similar concepts (see Panel C in Table 2). 
This analysis of the relevant text resulted in the thirty-six repeating groups listed in Table 3. These categories are created with the intent of letting the data speak for itself. Categories are created by identifying the concept of the initial relevant text from the first response and then applying this concept to the similar responses of all of the remaining participants. Then the next uncategorized relevant text is labeled, and the label is applied through out the remaining data, and so on until all of the relevant texts have an identifier. This is not a linear process, and some categories that prove to be too broad are redistributed into narrower groups. Some responses are ultimately combined together into a broader category. Some responses remain "orphans," which is to say there is only one response for a given concept. While the orphan information can indicate important individual differences and may suggest further study, the four "orphans" in this research are set aside entirely from the analysis in this paper. ${ }^{4}$ By letting the data develop the groupings, this paper identifies issues of importance to the participants that the researchers would never have asked about in a prepared survey and that the researchers may actually have ruled out as obviously not important to success in online learning of accounting. However, it is exactly these sorts of responses that can provide researchers with information that can improve the practice of accounting education. For example, four participants advised future students' to prepare before the class even begins by reviewing accounting concepts or obtain an "accounting for dummies" book. From the instructor's viewpoint this class has no prerequisites beyond admission to the MBA program, and this advice violates the school policy for its entry-point classes! However, these students are not wrong and may have identified an avenue for course improvement.

The repeating groups were then reviewed and sorted into common themes. The thirty-six repeat groups and the seven themes are listed in Table 3.

\section{RESULTS} themes.

The advice on preparation for an online graduate accounting course was categorized into seven different

\section{A. Input Factors for Success}

The most common advice given by 44 out of 62 participants and $35 \%$ of the overall responses was collected into the theme of the student input to the course required for success and labeled "Input Factors for Success." The number one advice was to allot sufficient time in one's schedule for the class. The top three recommendations were: Allot Sufficient Time, Don't Procrastinate, and Organize. The other repeating groups in order of frequency were: Stay Ahead, Put Forth Effort, and Meet Deadlines. Students had particular methods of implementing this advice that they shared extensively:

I would encourage them to create a plan dividing the work into days of the week starting on the Friday after the last unit closes. It became apparent that Friday was not too soon to start on the new unit and that Wednesday was really too late to start on the homework. The work load can be staggering so understanding deadlines and expectations will be critical to deliver credible work. I would suggest this type of schedule: Friday Do Current Event Posting Saturday Read Chapter Sunday Read/Listen to PowerPoint/Virtual Lecture Monday Do Company Analysis Tuesday Start Homework Thursday Take Quiz. Finish Company. (Student 43)

Sometimes students gave this advice because of their experience in not meeting this ideal.

A mistake I made, that you should not, is to review and printout all the materials ahead of the class. For example, there may be an excel spreadsheet with captions already included. What I did wrong was in doing the initial five or six spreadsheets individually before I realized there was a master sheet. What you need to do is stay ahead of the curve, keep up and know what's coming around the corner. (Student 6)

These online students understood their success as a result of their own input into the course and felt that their input into the course made a difference in their success in the course. In addition, this advice directly contradicts that myth that online courses can be taken when one doesn't have enough time for an on-campus course. 


\section{B. What Actions To Take}

The next most common theme was advice describing specific actions to take during a course. $19 \%$ of the participants specifically mention listening to the audio lectures included in the online course, $16 \%$ practice problems, $13 \%$ read the textbook, and $8 \%$ complete all assignments. Since these match the minimum expectations of instructors for the course, the advice was surprising - as if the participants expected the future students to take shortcuts in learning. Additional advice included actions that were not as obvious and not as pervasive: Use More Resources than the Textbook (6\%), Learn about Real Companies (5\%), Prepare Before the Course Begins (4\%), Keep Up with Current Events (3\%), and Learn the Accounting Vocabulary (3\%). In addition, students shared specific study techniques

- "Work the online practice test as if they were taking a real exam" (Student 6)

- "Search the course webpage for FAQs or insights to help you along the way" (Student 7)

- "Read the feedback given by the instructor" (Student 19)

- $\quad$ "Make your own outlines and know what the words mean" (Student 23)

This advice both mimics the course syllabus and goes beyond instructor's directions and expectations. Generally this advice confirms that the activities in the course have been useful to students, and their value may need to be emphasized to students prone to take shortcuts.

\section{Course-Based Characteristics}

Another tack that students took is describing the course to future students so that they could adequately prepare for it. $14 \%$ of the response from $39 \%$ of the participants are described by this theme. In fact, the repeating group of Prepare for a Difficult Course was stated by $19 \%$ of the participants - the fifth most common repeating group. Other repeating groups in this theme are Manage the Course Workload (8\%), Prepare for the Cumulative Nature of Accounting Knowledge (6\%), and Prepare for Harder Content through the Trimester (3\%). There is diversity in this group. Some students emphasize learning the early material so that one is prepared to understand the later material; others emphasize not being fooled by how easy the beginning material is because the later material gets harder. Certainly the authors affirm the validity of both sentiments.

My advice would be coming from my experience and would be quite simple. It would be to take heed to the basics and fundamentals of the course as it becomes crucial as the course progresses. Coming from a non-accounting background, I felt like the terms and basics were a foreign language. But instead of actually grasping the initial fundamentals, I attempted to continue hoping that I would be able to learn as I went. Simply stated, this was the wrong method and it caused me to utilize more time than I expected since I had to basically start from scratch and thoroughly learn the fundamentals. So to conclude, my advice is to grasp the terms and concepts from day one. (Student 2)

The first few chapters may lead one into a sense of false security as the material moves from "simple" debit and credit rules to more in depth concepts and principles of financial accounting. (Student 30)

Students commonly advise future students that online graduate accounting courses are hard and identify the overall workload, the cumulative nature of the subject matter, and the increasing difficulty throughout the semester as its cause.

\section{Communication for Success}

Communication was separated as a separate theme with two components. Students saw value in communication both with the instructor (24\%) and with their peers $(10 \%)$. Some students provide advice that would match with instructor presuppositions.

Never hesitate to ask the instructor any questions that you may have. Participate in the online chats because you can definitely learn from peers. (Student 19) 
However, students don't always see communication in the way that instructors would prefer.

Also, if you have questions about an assignment, the syllabus or even an accounting concept, do not hesitate to contact the professor for clarification. (Student 9)

The authors can testify that online instructors often feel that all of their communication to students is on the mechanics of using online tools, the directions for activities, and the failures of technology. No wonder! At least this one student also believes that instructors are the source of last resort for actually discussing accounting.

\section{Personal Factors for Success}

The next most commonly discussed theme is based on personal characteristics that affect success in an online graduate accounting class. Seven participants included warnings about who should avoid online graduate accounting classes. Some match the general advice given for those approaching online education.

- "If your plan is that the online course has less requirement in terms of your time and less course load, then my advice is that you should reconsider your plan." (Student 41)

- $\quad$ "I would recommend in addition to the above that if they are weak on numbers, consider taking it on campus." (Student 45)

However, some advice is hard for instructors to acknowledge.

- $\quad$ "It is not geared for working people and will seriously affect your life!" (Student 3)

- $\quad$ "If a fellow MBA student had asked me for my thoughts on taking Financial Accounting online I would begin by asking the student a question. Did you do well in Accounting as an undergraduate? Based on this answer I would have two opinions. If the answer was "yes", then I would say that taking this class online is a great option. The student would enjoy it and probably would do well in it given that he/she followed the provided agenda. If the answer was "no," I would probably recommend that the student take it in a classroom setting rather than online." (Student 26)

Since the online course involved is intended for working people and requires no accounting prerequisite, students who gave the above responses are providing advice that is directly against the policy for the course. Yet their experiences can't be ignored. It is hard for online instructors to affirm that there are some students whose learning style and situation may suggest on-campus settings over online settings. Are these two students in that category or can the online experience be improved for even them to be fully prepared for success?

On the other hand the positive characteristics leading to success in online graduate accounting courses are Persistence (5\%), Self-discipline (10\%), and "Serious" Attitude (6\%).

\section{F. Control of External Activities}

Twenty-four percent of the participants mentioned the impact of life activities external to the course are important for academic success. Nine participants recommended that students limit their courseload during the semester in which the students take an online graduate accounting course. Seven participants went one step further and recommended that students manage their work and home life to be able to succeed academically.

- $\quad$ Start working on Saturday and Sunday because you never know what your work week will throw at you. (Student 22).

- I I found that as the trimester continued and the fact that I began a new consulting assignment that required more of my time, I began to fall behind in the Practice Questions and the Learning Objectives. (Student 30)

- $\quad$ Since it was online, I think my boss and others at work were able to take advantage of the fact that I was just "at home" and not in class and therefore was able to call upon even during my tests. If I was in a class, there would have been no such confusion. (Student 11). 
This advice is for activities outside of the control of the instructor, and not completely within the control of the student either. Yet these externalities impact the student. No matter how well-designed and well-balanced an online course, success for working professionals with jobs and family includes their managing these interactions as well as the course itself.

\section{G. Technical Skills}

Finally, the participants offered advice on two technical skills: math skills and spreadsheet skills. While only $3 \%$ of these responses were in this area, it represented an area mentioned by $8 \%$ of the participants. Presumably this minority of students felt that the math and spreadsheet skills required in the online course could be significant impediments to success in the course. Thus even though this is a small issue among the participants, these skills are fundamental to completing an online course, and can be a serious barrier for unprepared students. One student advised as his or her first point, "I would suggest to anyone taking this course online, that they need to be comfortable with their math/algebra skill [sic] and know how to use a financial calculator or excel [sic]." (Student 16).

\section{v. CONCLUSION}

This paper uses the advice of MBA students for preparation for success in online graduate accounting classes to understand their experience and to impact the quality of online courses offered. This advice makes clear that the overwhelming factor to students is managing the time commitment in online classes. However, they also make recommendations in the areas of communications, course characteristics, personal characteristics, technical skills, external activities, and study activities that can help prepare future students for the online experience.

Table 1

Demographic Data on Participants

$\mathrm{n}=62$

\begin{tabular}{|l|l|l|}
\hline Descriptor & Category & Percentage \\
\hline Age & 30 and under & $26.67 \%$ \\
\hline & 31 to 40 & $43.33 \%$ \\
\hline Gender & 41 and over & $30.00 \%$ \\
\hline & Male & $56.45 \%$ \\
\hline Previous Accounting Course & Female & $43.55 \%$ \\
\hline & Yes & $37.10 \%$ \\
\hline & No & $48.39 \%$ \\
\hline Previous Online Course & Unknown & $14.52 \%$ \\
\hline & 0 & $59.68 \%$ \\
\hline & $1-2$ & $12.90 \%$ \\
\hline & $3-6$ & $16.13 \%$ \\
\hline Taking Only Online Courses & More than 6 & $11.29 \%$ \\
\hline & Yes & $50.00 \%$ \\
\hline Progress in Graduate Program & No & $50.00 \%$ \\
\hline & No previous courses & $41.94 \%$ \\
\hline & 1 to 9 credits previously & $29.03 \%$ \\
\hline & 10 to 24 credits previously & $22.58 \%$ \\
\hline Work Experience & More than 24 credits previously & $6.45 \%$ \\
\hline & 0 to 4 years & $37.10 \%$ \\
\hline & 5 to 10 years & $41.94 \%$ \\
\hline
\end{tabular}


Table 2

Student Response: Identification and Classification of Relevant Text

\section{Panel A: Student Response:}

(The "relevant text" is underlined and in bold and italics. This was added by the author.).

First and foremost, they will need to budget more time than they think to complete assignments and listen to lectures. Accounting is more than numbers and knowing what column to put them into. Accounting requires an understanding of how things work in the world. I find that this class makes much more sense to me now, 15 years after graduating college then when I took it in school. I can now relate these concepts to everyday life. The more experience a student has outside of school, the more they will value and understand this class. I would tell them to listen carefully to the lectures. Slides and reading the chapters are great, but the real understanding comes with the explanation from someone who has been there, done that and has real world examples. Lastly, I would tell them to not just do the required homework problems, but as many as the end of the chapter as they have time for. Their [sic] are so many ways to present a problem that you can get confused if you are only used to one view.

\section{Panel B: Categorization of Student Response}

Repeating Group: Allot Sufficient Time

they will need to budget more time than they think to complete assignments

Repeating Group: Listen to Lectures

and listen to lectures.

Repeating Group: Don't Take an Online Course If

The more experience a student has outside of school, the more they will value and understand this class. I would tell them to listen carefully to the lectures.

Repeating Group: Practice Problems

Lastly, I would tell them to not just do the required homework problems, but as many as the end of the chapter as they have time for. Their [sic] are so many ways to present a problem that you can get confused if you are only used to one view.

Panel 3: All Relevant Texts in Repeating Group of Practice Problems

\begin{tabular}{|c|l|}
\hline Student & \multicolumn{1}{c|}{ Text } \\
\hline 4 & $\begin{array}{l}\text { not just do the required homework problems, but as many as [sic] the end of the chapter as they have time for. } \\
\text { Their [sic] are so many ways to present a problem that you can get confused if you are only used to one view. }\end{array}$ \\
\hline 6 & Practice, Practice, Practice. Namely do your homework. \\
\hline 15 & do all your homework \\
\hline 16 & $\begin{array}{l}\text { do all of the practice homework; the homework repetition is what makes it stick in your head; practice or read } \\
\text { throughout the week. With accounting it is all about repetition and practice. If you put it down or away for a week } \\
\text { some of it gets forgotten }\end{array}$ \\
\hline 37 & practice and continual understanding of the relationships of all components \\
\hline 39 & practice the homework problems \\
\hline 40 & solve all end of chapter problems in textbook \\
\hline 46 & take advantage of every available opportunity to learn and practice the course material \\
\hline 47 & The more problems you work the better you understand \\
\hline 52 & work out more problems \\
\hline
\end{tabular}


Table 3

Repeating Ideas Summarized from Relevant Text

\begin{tabular}{|c|c|c|c|}
\hline Repeating Ideas & $\begin{array}{l}\text { Number of } \\
\text { Responses }\end{array}$ & $\begin{array}{l}\text { Percent of Participants } \\
\text { with a Response in this } \\
\text { Repeating Idea Group }\end{array}$ & Themes \\
\hline Allot sufficient time & 28 & $45 \%$ & A Input Factors for Success \\
\hline Don't Procrastinate & 21 & $34 \%$ & A Input Factors for Success \\
\hline Organize & 14 & $23 \%$ & A Input Factors for Success \\
\hline Stay ahead & 10 & $16 \%$ & A Input Factors for Success \\
\hline Put forth effort & 5 & $8 \%$ & A Input Factors for Success \\
\hline Meet Deadlines & 4 & $6 \%$ & A Input Factors for Success \\
\hline Listen to Lectures & 12 & $19 \%$ & B What Actions to Take \\
\hline Practice Problems & 10 & $16 \%$ & B What Actions to Take \\
\hline Read Text & 8 & $13 \%$ & B What Actions to Take \\
\hline Study In This Way & 7 & $11 \%$ & B What Actions to Take \\
\hline Complete All Assignments & 5 & $8 \%$ & B What Actions to Take \\
\hline Prepare Ahead & 4 & $6 \%$ & B What Actions to Take \\
\hline $\begin{array}{l}\text { Use More Resources than the } \\
\text { Textbook }\end{array}$ & 4 & $6 \%$ & B What Actions to Take \\
\hline Learn About Real Companies & 3 & $5 \%$ & B What Actions to Take \\
\hline Keep up with Current Events & 2 & $3 \%$ & B What Actions to Take \\
\hline Learn the Accounting Vocabulary & 2 & $3 \%$ & B What Actions to Take \\
\hline Prepare for a difficult Course & 13 & $21 \%$ & C Course-based Characteristics \\
\hline Learn the Basic Material Thoroughly & 8 & $13 \%$ & C Course-based Characteristics \\
\hline Manage the Course Workload & 5 & $8 \%$ & C Course-based Characteristics \\
\hline $\begin{array}{l}\text { Prepare for the Cumulative Nature of } \\
\text { Accounting Knowledge }\end{array}$ & 4 & $6 \%$ & C Course-based Characteristics \\
\hline $\begin{array}{l}\text { Prepare for Harder Content Through } \\
\text { the Trimester }\end{array}$ & 2 & $3 \%$ & C Course-based Characteristics \\
\hline Communicate with professor & 15 & $24 \%$ & D Communication for Success \\
\hline Communicate with peers & 6 & $10 \%$ & D Communication for Success \\
\hline $\begin{array}{l}\text { Don't take an Online Accounting } \\
\text { Course IF }\end{array}$ & 7 & $11 \%$ & E Personal Factors for Success \\
\hline Be Self Disciplined & 6 & $10 \%$ & E Personal Factors for Success \\
\hline Have a Serious Attitude & 4 & $6 \%$ & E Personal Factors for Success \\
\hline Be Persistence & 3 & $5 \%$ & E Personal Factors for Success \\
\hline Avoid Distractions & 7 & $11 \%$ & F Control of External Activities \\
\hline Take Only One Course At a Time & 7 & $11 \%$ & F Control of External Activities \\
\hline Take With an Easy Course & 2 & $3 \%$ & F Control of External Activities \\
\hline Practice Math Skills & 3 & $5 \%$ & G Technical Skills \\
\hline Practice Spreadsheet Skills & 3 & $5 \%$ & G Technical Skills \\
\hline Number of Participants & 234 & 62 & \\
\hline
\end{tabular}


Table 4

Themes in Online Preparation for Success in an Online Graduate Accounting Course

\begin{tabular}{|l|l|l|l|l|}
\hline \multicolumn{1}{|c|}{ Themes } & \multicolumn{1}{|c|}{$\begin{array}{c}\text { Number of } \\
\text { responses in } \\
\text { this theme }\end{array}$} & $\begin{array}{c}\text { Number of } \\
\text { Percent of } \\
\text { responses in } \\
\text { this theme }\end{array}$ & $\begin{array}{c}\text { Percent of } \\
\text { Participants with } \\
\text { at least one } \\
\text { response in this } \\
\text { theme }\end{array}$ & $\begin{array}{c}\text { Participants with } \\
\text { at least one } \\
\text { response in this } \\
\text { theme }\end{array}$ \\
\hline A Input Factors for Success & 82 & $35 \%$ & 44 & $71 \%$ \\
\hline B What Actions to Take & 57 & $24 \%$ & 32 & $52 \%$ \\
\hline C Course-Based Characteristics & 32 & $14 \%$ & 24 & $39 \%$ \\
\hline D Communication for Success & 21 & $9 \%$ & 16 & $26 \%$ \\
\hline E Personal Factors for Success & 20 & $9 \%$ & 15 & $24 \%$ \\
\hline F Control of External Activities & 16 & $7 \%$ & 15 & $24 \%$ \\
\hline G Technical Skills & 6 & $3 \%$ & 5 & $8 \%$ \\
\hline Total & $\mathbf{2 3 4}$ & & $\mathbf{6 2}$ & \\
\hline
\end{tabular}

\section{AUTHOR INFORMATION}

Dr. Robert Walsh holds a Ph.D. in economics from Notre Dame University and is an associate professor of accounting at the Graduate School of Management of the University of Dallas. He teaches tax, managerial accounting, and financial accounting, both online and in the classroom.

Dr. Barbara W. Scofield holds a Ph.D. in accounting from the University of Texas at Austin and is an associate professor of accounting at the Graduate School of Management of the University of Dallas. She teaches financial accounting and accounting information systems both online and in the classroom.

\section{REFERENCES}

1. Accounting Education Change Commission (AECC). (1990). Objectives of education for accountants: Position Statement Number One. Issues in Accounting Education, 5, 307-312.

2. Albrecht, W and Sack, R. (2000). Accounting Education: Charting the Course Through a Perilous Future. Accounting Education Series, Vol. 16. American Accounting Association, Sarasota, Florida.

3. American Accounting Association, Committee on the Future Structure, Content and Scope of Accounting Education. (1986). Future accounting education: Preparing for the expanding profession. Issues in Accounting Education, 1, 168-195.

4. Auerback, C. F. and Silverstein, L. B. (2003). Qualitative Data: An Introduction to Coding and Analysis. (New York: New York University Press).

5. Bergin, J. (1983). The Effect of Previous Accounting Study on Student Performance in the First Collegelevel Financial Accounting Course. Issues in Accounting Education, 8, 1. 19-21

6. Biner, P., Bink, M., Huffman, M. and Dean, R. (1995) Personality Characteristics Differentiating and Predicting the Achievement of Televised Course Students and Traditional-Course Students. The American Journal of Distance Education. 9, 2. 46-60.

7. Big Eight Accounting Firms. (1989). Perspectives on Education: Capabilities for Success in the Accounting Profession ("The White Paper"). New York, New York.

8. Brown, R. and McCartney, S. (1998). Using Reflections in Postgraduate Accounting Education, Accounting Education, 7, 2, 123-137.

9. Bryant, S., Kahle, J and Schafer, B. (2005). Distance Education: A Review of the Contemporary Literature, Issues in Accounting Education. 20, 3, 255-272.

10. Byrne, J. (1991). Weekend Warriors: A Guide to MBAs for Working Execs. Business Week (October 28), 109-114.

11. Chewning, E. and Spiller, E. (1999). Validation of Factors Relevant to the Exemption of Accounting Coures in MBA programs. Journal of Accounting Education. 17, 2. 123-126. 
12. Davidson, R. and Baldwin, B. (2005). Cognitive Skills Objective in Intermediate Accounting Textbooks: Evidence from the End-of-Chapter Material. Journal of Accounting Education. 23, 2. 79-87.

13. Danvers, K. (2006). Increasing the Relevance of Undergraduate Accounting Education, Strategic Finance. May, Vol 87, 21-24.

14. Evans, P and Foster, E. (1997). Teaching Accounting to Overseas MBA Students: Exploring an Alternative Method. Accounting Education, 6, 3, 231-245.

15. Gist, W., Goedde, H., and Ward, B. (1996). The Influence of Mathematical Skills and Other Factors on Minority Student Performance in Principles of Accounting. Issues in Accounting Education. 11,1. 49-60.

16. Hermanson, D., Hermanson, H.\& Alsup, R. (1998). The Accounting Component of Executive MBA Programs. Issues in Accounting Education. 13, 4, 801-814.

17. Horngren, C. T., Sundem, G. L., Elliott, J. A., and Philbrick, D. R. (2006). Introduction to Financial Accounting. (Upper Saddle River, New Jersey: Pearson Prentice Hall).

18. Hunton, J., Stone, D., \& Wier, B. (2005). Does Graduate Business Education Contribute to Professional Accounting Success. Accounting Horizons. 19, 2, 85-101.

19. Irizarry, R. (2002) Self-Efficacy and Motivation Effects on Online Psychology Student Retention. USDLA Journal. 16, 12. 55-64.

20. Krausz, J., Schiff, A., Schiff, J., and VanHise, J. (1998) The Effects of Prior Accounting Work Experience and Education on Performance in the Initial Graduate-Level Accounting Course. Issues in Accounting Education, 14, 1, 1-10.

21. Leonhardt, D. (2000). A matter of degree? Not for consultants. The New York Times. (October 1): 1-7.

22. Levy, E. \& Klein, L. (1993). Massachusetts practitioners speak out on how future CPAs should be educated. Massachusetts CPA Review. 67(2), 22-23.

23. Mintzberg, H., \& Lampel, J. (2001). Do MBAs make better CEOs? Sorry, Dubya, it ain't necessarily so. Fortune. 143: 244.

24. _ \& Gosling, J. (2002). Reality programming for MBAs. Strategy + Business Magazine. 1-5

25. Muirhead, B. (2002). Promoting Online Interaction in Today's Colleges and Universities. USDLA Journal. 17, 2. 63-69.

26. Needles, Jr., B. \& Powers, M. (1990). A comparative study of models for accounting education. Issues in Accounting Education. 5(2), 250-267.

27. Novin, A., Fetyko, D. \& Tucker, J. (1997). Perceptions of accounting educators and public accounting practitioners on the comparison of 150 hour accounting programs: A comparison. Issues in Accounting Education. 12(2), 331-352.

28. Palloff, R. and Pratt, K. (1999). Building Learning Communities in Cyberspace. San Francisco, California: Jossey-Bass.

29. Pfeffer, J., \& Fong, C. (2002). The End of Business Schools? Less Success Than Meets the Eye. Academy of Management Learning and Education. 1, 1-17.

30. Pratt, M. and Davey, H. (1997) Future Directions in Accounting Education. Chartered Accountants, 76, 1, 15-18.

31. Rudnick, M. and Taylor, V. (2004). Do College Accounting Curriculums Teach to the CPA Exam? Should They Try? Journal of College Teaching and Learning. 7, 23-30.

32. Robyler, M. and Wiencke, W. (2003). Design and Use of a Rubric to Assess and Encourage Interactive Qualities in Distance Courses. The American Journal of Distance Education. 17, 2. 77-98.

33. Siegel, G. and Sorenson, J. (1999). Counting More, Counting Less: Transformations in the Management Accounting Profession, 1999 Practice Analysis of Management. Institute of Management Accountants, Montvale, New Jersey.

34. Simonson, M., Schlosser, C. and Hanson, D. (2002) Theory and Distance Education: A New Discussion. In Distance Education: Teaching and Learning in Higher Education, edited by L. Foster, B. Bower and L. Watson. Boston, Massachusetts: Pearson Publishing.

35. Teo, S., Ghosh, B. and Low, M. (1993). Employers' Perceptions of the Education and Performance of Accounting Graduates. Singapore Accountant. Oct/Nov, 24-26.

36. Vesely, P., Bloom, L. and Sherlock, J. (2007) Key Elements of Building Online Community: Comparing Faculty and Students Perceptions. Journal of Online Learning and Teaching. 3, 3. 1-12.

37. Walsh, R. (1999) ALN/WBI: An Introduction and an Application to the Accounting Information Systems Course. The Review of Accounting Information Systems. 3, 4. 27-38. 
38. Watson, S., Apostolou, B., Hassell, J. and Webber, S. (2003). Accounting Education Literature Review. Journal of Distance Education. 13, 3. 22-36.

39. Zabriskie, F. and McNabb, D. (2007) E-hancing the Master of Business Administration (MBA) Managerial Accounting Course, Journal of Education for Business. 82, 4, 226-234.

\section{Endnotes}

${ }^{1}$ Students had to have six credits of undergraduate accounting with a grade of at least B- taken in the last 8 years to waive this course.

${ }^{2}$ Auerback and Silverstein (2003) prefer to use the research constructs of systematic and transparent rather than the more traditional constructs of validity and reliability that are used with empirical sciences. The goal in this project is to carry out a systematic research process that is objective and does not allow researcher biases to affect the outcome. In addition, the results presented will be fully described so that readers understand how the source of the results discussed in this paper. Varying interpretations of the data are possible, but there should be clear understanding of how this particular interpretation is derived.

${ }^{3}$ Additional researchers will be completing parallel analysis of this data. The results will then be compared and converged to produce a set of categories with greater assurance of having identified major themes in the data. Unlike more traditional empirical categorization, categories are not predefined which makes coding a mechanical process with one correct result. Instead the means by which two researchers frame a dataset are expected to have variations and to provide for additional insight to improve the categorization over that which is done by each researcher alone. In addition, Auerbach and Silverstein (2003) have a consultant who shares the important characteristics with the participants to review the categorization for its reasonableness and to correct any misinterpretations. The director of distance education at the university, who herself holds an online graduate business degree, will serve as this consultant for this project.

${ }^{4}$ Take Financial Accounting as the First MBA Course, Question Grading, Relax, and Understand Theory are the four potential repeating groups of advice which had only one response each. 


\section{NOTES}

